\section{Commonwealth Students in Britain}

IN a written answer in the House of Commons on July 16, Mr. A. E. Oram, the Parliamentary Secretary to the Ministry of Overseas Development, gave the number of students from each of the Commonwealth countries taking full-time courses in the United Kingdom in the academic years 1959-60 - 1963-64. To the total, which had risen from 30,169 in $1959-60$ to 35,664 in $1960-61,39,122$ in $1961-62,42,094$ in $1962-63$, and 42,322 in 1963-64, Nigeria, with $6,000,6,800,7,836,8,954$ and 8,630 , respectively, was the largest individual contributor, followed by India, with $3,510,3,400,3,496,4,281$ and 4,129. Malaya, with $2,200,2,220,2,428,2,496$ and 2,882 ; Ghana $(1,840$, $3,793,3,348,1,885$ and 1,991); Jamaica (1,940, 2,980, $3,151,4,083$, and 3,841$)$; followed by Hong Kong (1,550, $1,580,1,559,1,619$ and 1,715$)$ and Pakistan (1,570, $1,245,1,470,1,711$ and 1,924) came next. Trinidad and Tobago $(1,100,1,370,1,622,1,858$ and 1,844) and Kenya $(1,030,1,272,1,592,1,532$ and 1,593$)$ were the only other countries to send more than 1,000 a year until $1960-61$ when this figure was exceeded by Barbados; in 1961-62 it was also exceeded by Uganda, in 1962-63 by British Guiana, and in 1963-64 by Ceylon and Cyprus.

\section{Postgraduates at Universities in Britain}

Is a written answer in the House of Commons on August 4, Mr. A. Crosland, the Secretary of State for Education and Science, stated that the number of postgraduates at universities in Britain had risen from 1,400 in $1920-21$ and 2,237 in $1930-31$ to 11,327 in $1950-51$, 12,668 in $1955-56,17,836$ in $1960-61$ and 24,255 in $1964-65$.

\section{Medical Research and Work Study}

IN a written answer on July 16, Mr. A. Crosland stated that expenditure by Government agencies, including the Medical Research Council, the Health Departments, Ministry of Defence, and the proportion devoted to medical research from the general grant to the universities, is estimated at $£ 5.5$ million in $1954-55, £ 6.5$ million in $1955-56$, and $£ 7$ million in $1956-57$, rising to $£ 14.5$ million in $1961-62, £ 16$ million in $1962-63, £ 18.5$ million in $1963-64$ and $£ 23$ million in 1964-65. No reliable estimate could be given of expenditure on medical reserrch by other bodies including the pharmaceutical industry and voluntary organizations. During the academic year 1964-65, 623 students attended the Work Study School at the Royal College of Aeronauties, Cranfield, and, of its income of $£ 55,165, £ 55,131$ was from fees paid by sponsoring firms and organizations. For the same year, the College received a recurrent grant of $£ 865,000$ and non-recurrent grant of $£ 96,005$, as well as a capital grant of $£ 28,995$; for $1965-66$ these were estimated at $£ 825,000, £ 66,500$ and $£ 103,500$, respectively. The College was the only exclusively postgraduate technological teaching institute of its kind in Britain, and the net cost per student had been reduced to a little more than $£ 2,000$ in the current year.

\section{Industrial Training Boards}

IN replying for the Government on July 29 to a Motion to annul the Industrial Training Levy (Engineering) Order, of June 11, 1965, Mr. R. Marsh, the Joint Parliamentary Secretary to the Ministry of Labour, said that the Engineering Board Levy of 2.5 per cent was likely to yield about $£ 80$ million in the first year. Direct Treasury assistance to the boards up to March 31 was about $£ 135,000$, apart from other assistance, such as senior staff, and during the current year direct Government grant to the boards would be about $£ 1.5$ million, compared with approaching $£ 100$ million from the levies, and none of this money would leave the industry. The Motion was withdrawn. In a written answer on August 2, Mr. R. J. Gunter, the Minister of Labour, who had previously given the names of the chairman and deputy-chairman and members of the Ceramics, Glass and Mineral Industry Training Board, stated that, in January-June 1965, 35,434 boys and 5,717 girls gained apprenticeships on first entering employment, or 37.2 per cent and 6.5 per cent, respectively, compared with $34,221(32 \cdot 6$ per cent) and $6,030(6 \cdot 1$ per cent), respectively, in January-June 1964.

\section{In-Service Training for Teachers of Mathematics}

THE serious shortage of teachers of mathematics will not be remedied by any single stroke, but one contribution to the solution of the problem lies in the development of in-service training, whereby those already teaching may be encouraged to revise and extend their knowledge of mathematics and so to fit themselves for coping with modern trends in mathematics and for undertaking greater responsibilities. Several institutes of education have provided excellent courses to this end, but much remains to be done, and the Joint Mathematical Council now offers a short report by its working party, in which a national scheme is propounded (Report on In-Service Training for Teachers of Mathematics. Pp. 12. London: Prof. J. G. Semple, Hon. Secretary, Joint Mathematical Council of the United Kingdom, c/o King's College, 1965). It suggests : (i) the setting up of mathematics centres to provide the necessary facilities, under local education authorities; (ii) the establishment by each institute of education of an advisory unit; (iii) that the Schools Council for the Curriculum and Examinations should set up a permanent sub-committee to recruit and train key personnel and to obtain necessary funds; (iv) the establishment of a national information centre to link together all people concerned and to provide information on all relevant topics. The report does not waste time and paper on deploring the present situation, but concisely and forcefully makes precise suggestions for the development and organization of a valuable constituent in any final solution of an urgent problem.

\section{Information and Communication}

Focus on Information and Communication, recently issued by Aslib and edited by Barbara Kyle, includes seven papers (Pp. viii + 113. London: Aslib, 1965. 14s.). It incorporates Barbara Wootton's two papers on problems in communications (reprinted from Aslib Proceedings, November 1953 and November 1954); A. R. Meetham's paper on preliminary studies for machine-generated index vocabularies (Language and Speech, January-March 1963); W. T. Williams's paper on "Computers as Botanists" (Nature, 179, 146; 1963); R. Crawshay-Williams's paper on "The Double Criterion of Empirical Judgment" (previously circulated privately in duplicated form); Prof. P. Meredith's "Documents, Programmes and TopicsSome Observations on Topic Analysis" (based on two earlier papers on topic analysis and an analysis of relations); Prof. J. K. Feibleman's "The Integrating Levels in Nature" (a revised version of an earlier paper in the British Journal for the Philosophy of Science in 1954).

\section{Scientific Information Notes}

THE June-July 1965 issue of Scientific Information Notes $(7$, No. $3 ; 1965)$, issued by the National Science Foundation, includes further information on the two-year experimental programme to provide a rapid source of chemical information for which the Science Adviser to the President has announced a 2-million dollar contract between the Foundation and the American Chemical Society. It provides for the establishment, by the Society's Chemical Abstracts Service, of a computer-based registry system for chemical compounds based on chemical structure and for selected research. It is expected that 